\title{
PRODUCTION, CONSUMPTION AND PRICE (IMPORTS, PRODUCERS AND CONSUMER) VOLATILITY OF SHALLOT IN PROBOLINGGO REGENCY
}

\author{
Susanti Evie Sulistiowati ${ }^{1 *}$, Ratya Anindita ${ }^{2}$, Rosihan Asmara ${ }^{2}$ \\ ${ }^{1}$ Postgraduate of Agriculture Economics Program, Faculty of Agriculture, Brawijaya University, \\ Indonesia \\ ${ }^{2}$ Faculty of Agriculture, Brawijaya University, Indonesia \\ *corresponding author: susantievie02@gmail.com
}

\begin{abstract}
Changes in production, consumption, and import variables cause the price of shallots to fluctuate. A high and unpredictable price fluctuation increasing the volatility problem. This phenomenon gives results in risk, uncertainty and leading to a decline in the welfare of producers and consumers. Based on the description of the problems above, it is important to analyze price, production, import, and consumption volatility to determined the level of risk and uncertainty faced by producers and consumers. This study uses monthly secondary data (time series) on production, price, imports, and consumption of shallots in Probolinggo Regency, for seven years (20132019). The ARCH/GARCH method is used to analyze the volatility of prices, production and consumption. The results from the analysis are the production variable has a low level of volatility, the consumption and import prices have high-level volatility, producer price has low-level volatility, while consumer prices has-high level volatility. From the results means that the risks and uncertainties faced by producers in conducting shallot cultivation are low. While for the consumer means the risks and uncertainties in consuming shallots are high.
\end{abstract}

Keywords: Consumption, Import, Production, Shallot, Volatility

http://dx.doi.org/10.21776/ub.agrise.2021.021.3.8

Received 8 April 2021

Accepted 25 July 2021

Available online 31 July 2021

\section{INTRODUCTION}

Shallot is one of the leading vegetable commodities that have high economic value. The consumption of shallots in Indonesia is currently increasing (Sahara, et. al. 2019). For the 2015-2019 period, the consumption of shallots has increased, with an average increase of $3.25 \%$. However, the increase in consumption that occurred was not fulfilled by the production. Production of 2015-2019 only increased by an average of $2.8 \%$ lower than the increase in consumption (BPS, 2019).

As an effort to fulfill consumption, the government imports shallots. Imports of shallots are carried out from December to April of the following year when production decreases, which usually occurs during the rainy season. The average import of shallots for the 2015-2019 period is 18,485 tons per year. Meanwhile, exports are carried out starting in October when production is abundant. During the 2015-2019 period, the average export was 3,411.9 tons per year (Ministry of Trade, 2019). The average number of imports-exports shows that imports of shallots are higher when compared to exports. This shows that domestic production is unable to meet consumption needs.

As a result of changes in production, consumption, and import prices, it causes price variations and fluctuations (Anindita, 2008). In general, the development of shallot prices at the producer and consumer levels in the 2015-2019 period shows an increasing trend with an average of $9.1 \%$ per year at the producer level and $16.9 \%$ per year at the consumer level (BPS, 2019). Price fluctuations can be a domestic threat and worry many parties, such as consumers and producers of shallots. Unpredictable price fluctuations will cause uncertainty in the price of shallots, where there is no certainty of how much the price will go up or down. This uncertainty is usually called the volatility problem. According to Hugida (2011), high price volatility will reflect unusual supply and demand characteristics or price tendencies to change beyond expectations. A high degree of volatility can increase CITATION: Sulistiowati, S. E., Anindita, R., Asmara, R., (2021). Production, Consumption and Price (Imports, Producers and 
risks for producers and consumers as well as raise concerns about stabilizing the market and the economy as a whole.

Based on the description that has been described, it is important to analyze of price volatility, production, imports, consumption, and also spillover volatility to determine the level of risk and uncertainty faced by producers and consumers. The benefits of this research will later provide information as material in formulating an appropriate policy recommendation so that the government can provide price regulation and improve the agricultural system as an effort to achieve stability of shallot commodity prices and help anticipate risks and uncertainties faced by producers and consumers.

\section{RESEARCH METHODS}

This research was conducted in Probolinggo Regency on November 2020. The determined of data used monthly data on production, consumption and prices (imports, producers and consumers) of shallots for seven years, starting from 2013 to 2019. The data source comes from the Central Bureau of Statistics, the Department of Agriculture and Cooperatives of Probolinggo Regency.

ARCH/GARCH model is an analytical method used to analyze the volatility of production, consumption and prices (imports, producers and consumers). The stages in analyzing using the ARCH / GARCH method will be explained below:

1. Data Stationarity Test with ADF Test (Augmented Dickey Fuller Test)

Time series data has the possibility of being nonstationary, which if regressed can cause a sporious regression phenomenon, so it is necessary to certain whether the data used is stationary or not (Gujarati, 2006). The stationary test is doing by the unit root test. This stationary test used ADF (Augmented Dickey-Fuller) model. With the test criteria namely, if the ADF probability value is greater than the $5 \%$ significance level $(\alpha=0.05)$ then accept H0, which means that the data has a unit root or the data is not stationary, and vice versa, if the ADF probability value is smaller than the level $5 \%$ significance $(\alpha=0.05)$ then reject $\mathrm{H} 0$, which means that the data does not experience a unit root or the data is stationary.

2. Testing the existence of the ARCH Effect

Testing for the presence of the ARCH effect is carried out using the Lagrange Multiplier or ARCH-LM test. The criterion in this test is if the probability value of the LM test is greater than the 5\% significance level, then accept $\mathrm{H} 0$, which means there is no ARCH effect and vice versa if the probability value of the LM test is less than the $5 \%$ significance level, then reject $\mathrm{H} 0$, which means that there is an ARCH Effect.
3. Estimation and Selection of the ARCH-GARCH Model

The selection of the ARCH/GARCH model for each variable is used to determine the level of volatility that occurs. The ARCH/GARCH model was selected by testing the model contained $\mathrm{ARCH}$ error elements through the heteroscedasticity test. It is said to be free from $\mathrm{ARCH}$ error when the probability value is greater than the 5\% significance. ARCH / GARCH model testing is carried out on production, consumption and price variables (imports, production and consumption). The ARCH / GARCH model for the five variables adopted from the Bollersslev (1986) model is as follows:

$$
\begin{aligned}
& \sigma^{2} P P=\alpha_{0}+\alpha_{1} \varepsilon^{2} P P_{t-1}+\beta_{1} \sigma^{2} P P_{t-1}+\varepsilon(1) \\
& \sigma^{2} C P=\alpha_{0}+\alpha_{1} \varepsilon^{2} C P_{t-1}+\beta_{1} \sigma^{2} C P_{t-1}+\varepsilon(2) \\
& \sigma^{2} I M P=\alpha_{0}+\alpha_{1} \varepsilon^{2} I M P_{t-1}+\beta_{1} \sigma^{2} I M P_{t-1}+ \\
& \varepsilon(3) \\
& \sigma^{2} P R D=\alpha_{0}+\alpha_{1} \varepsilon^{2} P R D_{t-1}+\beta_{1} \sigma^{2} P R D_{t-1}+ \\
& \varepsilon(4) \\
& \sigma^{2} K N S=\alpha_{0}+\alpha_{1} \varepsilon^{2} K N S_{t-1}+\beta_{1} \sigma^{2} K N S_{t-1}+ \\
& \varepsilon(5) \\
& \text { Given: } \\
& \sigma^{2} \quad=\text { The response variable (tied) to time } \mathrm{t} \\
& \text { or the variability of the current } \\
& \text { residuals } \\
& \alpha_{0} \quad=\text { Constant } \\
& \varepsilon_{t-1}^{2}=\text { The ARCH term Volatility in the } \\
& \text { previous period } \\
& \alpha_{1}, \beta_{1}=\text { Estimation Coefficient } \\
& \sigma_{t-1}^{2}=\text { The GARCH term the residual } \\
& \text { diversity of the previous period } \\
& P P \quad=\text { Price of shallots at the Producer } \\
& \text { Level } \\
& (\mathrm{Rp} / \mathrm{Kg}) \\
& C P \quad=\text { Price of shallots at the Consumer } \\
& \text { Level } \\
& \text { ( } \mathrm{Rp} / \mathrm{Kg}) \\
& I M P=\text { Import price of shallots }(\mathrm{Rp} / \mathrm{Kg}) \\
& P R D=\text { Production price of shallots (Ton) } \\
& K N=\text { Consumption price of shallots (Ton) } \\
& \varepsilon=\text { Term error factor in period } \mathrm{t}
\end{aligned}
$$

Based on the model used above, the sum of the coefficient $\alpha_{1}+\beta_{1}$ in each model will describe the level of volatility. $\alpha$ is the ARCH value and $\beta$ the GARCH value. The criteria for this level of volatility are:

If $\alpha_{1}+\beta_{1}$ is smaller than 1 then the price volatility that occurs is low (low volatility).

If $\alpha_{1}+\beta_{1}$ is equal to 1 then the price volatility that occurs is high (high volatility).

If $\alpha_{1}+\beta_{1}$ is greater than 1 , the price volatility that occurs is very high (high volatility). 


\section{RESULTS AND DISCUSSION}

\section{Data stationary Test}

Based on Table 1, it is found that the ADF probability value for all variables (production, consumption, import prices, producer prices, and consumer prices) shows greater than the significance level of 0.05 and the ADF statistical value is greater than the critical test value. This shows that the hypothesis used is to accept $\mathrm{H} 0$, which means that the data from the five research variables have unit roots or the data is not stationary. So according to research conducted by Moledina et. al. (2003) and Sumaryanto (2009), when the data used in the study are not stationary in the data stationarity test, the method used to analyze volatility is the ARCH / GARCH method.

Table 1. Stationarity Test Results

\begin{tabular}{lccc}
\hline \multicolumn{1}{c}{ Variable } & $\begin{array}{c}\text { Test } \\
\text { Critical } \\
\text { Value }\end{array}$ & $\begin{array}{c}\text { ADF } \\
\text { Statistic }\end{array}$ & Probabilit \\
\hline Production & -4.773194 & -2.302511 & 0.3767 \\
Consumption & -4.783195 & -2.405708 & 0.3537 \\
Import Price & -4.773195 & -0.804272 & 0.8851 \\
Producer Price & -4.072415 & -3.536296 & 0.4020 \\
Consumer Price & -4.073416 & -3.479058 & 0.4083 \\
\hline \multicolumn{4}{l}{ Source. Primary Data $(2020)$} \\
\end{tabular}

Source: Primary Data (2020)

\section{Testing the existence of the ARCH Effect}

Based on Table 2, it is found that the LM test probability value is smaller than the $5 \%$ significance level on all variables (production, consumption, import prices, producer prices, and consumer prices). This shows that the hypothesis used is rejected $\mathrm{H} 0$, which means that the data for all variables are indicated by the ARCH Effect, which is then carried out to determine the ARCH / GARCH order.

$\underline{\text { Table 2. ARCH Effect Testing }}$

\begin{tabular}{|c|c|c|}
\hline Variable & $\begin{array}{c}\text { Proba- } \\
\text { bility }\end{array}$ & Information \\
\hline Production & 0.0000 & $\begin{array}{c}\text { There is an ARCH } \\
\text { Element }\end{array}$ \\
\hline Consumption & 0.0000 & $\begin{array}{c}\text { There is an ARCH } \\
\text { Element }\end{array}$ \\
\hline Import Price & 0.0000 & $\begin{array}{c}\text { There is an ARCH } \\
\text { Element }\end{array}$ \\
\hline Producer Price & 0.0250 & $\begin{array}{c}\text { There is an ARCH } \\
\text { Element }\end{array}$ \\
\hline Consumer Price & 0.0001 & $\begin{array}{c}\text { There is an ARCH } \\
\text { Element }\end{array}$ \\
\hline
\end{tabular}

Source: Primary Data (2020)

\section{Estimation and Selection of ARCH / GARCH Models}

Based on Table 3, its found that the model chosen in estimating volatility for all variables (production, consumption, import prices, producer prices, and consumer prices) has a probability value greater than
$5 \%$, which means that the model is free from heteroscedasticity problems.

Table 3.Heteroscedasticity Test Results

\begin{tabular}{lcc}
\hline \multicolumn{1}{c}{ Variable } & $\begin{array}{c}\text { Proba- } \\
\text { bility }\end{array}$ & \multicolumn{1}{c}{ Information } \\
\hline Production & 0.1091 & No Heteroscedasticity \\
Consumption & 0.1749 & No Heteroscedasticity \\
Import Price & 0.1850 & No Heteroscedasticity \\
Producer Price & 0.1091 & No Heteroscedasticity \\
Consumer Price & 0.1749 & No Heteroscedasticity \\
\hline \multicolumn{2}{l}{ Source: Primary Data (2020) }
\end{tabular}

\section{Production Volatility}

The measurement of production volatility is seen through the results in the GARCH model $(1,1)$ with the GARCH equation, which is as follows:

$$
\begin{aligned}
& \sigma^{2} P R D t=2057394+(-0,422525) \varepsilon_{P R D t-1}^{2} \\
& 1,329898 \sigma^{2}{ }_{P R D t-1} \\
& \text { Given: PRD }=\text { Production }
\end{aligned}
$$

The volatility of shallot production has low level volatility. The low volatility here reflects that shallot production flows with less sharp changes (increase/decrease). This caused by shallots planted throughout the year and production is relatively stable. The level of fluctuation will have an impact on the volatility problems that will be faced by producers in conducting cultivation. This is as explained by Paranata and Ahmad (2015) when production is stable, then the price will move stably and the tendency of price volatility problems faced by producers is low. It caused by the high gap between production and consumption variable and also the influence from the price of import shallot.

\section{Consumption Volatility}

The measurement of consumption volatility is seen through the results in the GARCH model $(1,1)$ with the GARCH equation, which is as follows:

$$
\begin{aligned}
& \sigma^{2} \text { KNSt }=191742+(-0,721634) \varepsilon^{2}{ }_{K N S t-1}+ \\
& 1,737496 \sigma^{2}{ }_{K N S t-1}
\end{aligned}
$$

The volatility of shallot consumption has high volatility. The high volatility here reflects that the consumption of shallots is relatively fluctuating and has experienced sharp changes (increase/decrease). The level of fluctuation will have a high impact on the volatility problem that will be faced by consumers in consuming shallots. The higher the fluctuation of demand that occurs will have the potential to increase the problem of volatility. This fluctuation in consumption is caused by several factors, such as consumer buying patterns that are not routinely carried out. The consumption of shallots experiences a high enough increase on religious holidays (Galungan, Eid Al Adha, Eid AlFitr, Isra and Mi raj, Good Friday, Ascension of Jesus, Kuningan and the Birthday of Prophet 
Muhammad SAW) and the new year. This statement is supported. by (Putri and Watemin, 2014) which can trigger an increase in the commodity demand in an area. The other reason is the high gap that occurs between the production and consumption variables. Its about $66 \%$ of the total consumption.

\section{Import Volatility}

The measurement of import volatility is seen through the results in the GARCH model $(1,1)$ with the GARCH equation, which is as follows:

$$
\begin{gathered}
\sigma^{2} I M P t=4454462+2,868124 \varepsilon_{I M P t-1}^{2}+(- \\
\quad 0,374226) \sigma_{I M P t-1}^{2} \\
\text { Given: IMP = Import }
\end{gathered}
$$

The volatility of import prices in Probolinggo Regency has high level volatility. The high volatility of import prices here reflects fluctuating import prices has experienced sharp changes (increases/decreases). This is thought to be the result of high consumption volatility. When domestic needs cannot be fulfilled by production, the government imports. Shallots are a staple necessity that causes the elasticity of this commodity to prices, is inelastic or import demand is not influenced by price. The price of imported shallots is positively related to the carried out import demand. The effect of the price in accordance with the law of demand for ceteris paribus does not occur on the demand for imports of shallots (Pasaribu and Daulay 2013). Another factor that affects it, namely the world oil and gas prices. When there is an increase in oil and gas prices, it will have an impact on increasing commodity prices, consumption, investment and stock prices (Nizar, 2012).

\section{Producer Price Volatility}

The level producer price volatility of shallot is obtained by selecting the best model $\operatorname{GARCH}(3,2)$ with the following equation:

$$
\begin{aligned}
\sigma^{2} P P t= & 861966,5+0,923946 \varepsilon^{2}{ }_{P P t-1}^{+} \\
& (-0,7719877) \varepsilon^{2}{ }_{P P t-2}+ \\
& (-0,569333) \varepsilon^{2}{ }_{P P t-3}+0,609911 \\
& \sigma^{2}{ }_{P P t-1}+0,611858 \sigma^{2}{ }_{P P t-2}
\end{aligned}
$$

Given: $\mathrm{PP}=$ Producer Price

The price volatility of shallots at the producer level has low level volatility. It means that risks and uncertainties faced by producers in conducting shallot cultivation are relatively low. When the fluctuation that occurs in production is low, it will have an impact on low price fluctuations at the producer level. This is in accordance with the research of Pardian et. al. (2016) which suspected that the volatility of producer prices is at a low volatility level which is influenced by the occurrence of low production volatility, causing low producer prices.

\section{Consumer Price Volatility}

The level volatility of shallot consumer prices is obtained from the best model, GARCH $(1,4)$ with the following equation:

$$
\begin{aligned}
& \sigma^{2} C P t=16200038+0,837410 \varepsilon_{C P t-1}^{2}+(- \\
& \text { 0,071911) } \sigma_{C P t-1}^{2}+0,296904 \sigma_{C P t-2}^{2}+ \\
& 0,178051 \sigma_{C P t-3}^{2}(-0,204044) \sigma_{C P t-4}^{2}
\end{aligned}
$$

The price volatility of shallots at the consumer level has high level volatility. It means that the risks and uncertainties faced by consumer in consuming shallots are high. This caused by the asymmetry of information received between producer and consumers and hoarding activities carried out by retailers and wholesalers. This hoarding harms on the amount and time of onions circulating in the market so that it will have an impact on increasing the price received by consumers (Sarjani et. al. 2018). The other factor is the presence of imported shallots that makes the price of local shallots higher when compared to the price of imported shallots and reduces consumer interest in buying. As a result, farmers do not have the incentive to increase their shallot production.

\section{CONCLUSION}

Based on the research results on the volatility analysis, it was found that the production variable show a low level of volatility. This is due to production farmer that are carried out throughout the year and are relatively stable. It means that the high of price is not being an incentive to increase the amount of production. Then the consumption and import price variables show high volatility, which is caused by the high of gap between production and consumption, irregular buying patterns, spikes in demand on religious holidays and the influence of oil and gas prices. Furthermore, the producer price variable shows low volatility as a result of the effect of low production volatility and consumer prices show high volatility as a result of information asymmetry, length of marketing channels and hoarding activities.

Effort to stabilizes price, government needs to carry out several activities such as the first, doing market operations. This activity is carried out in order to minimize hoarding activities by irresponsible parties. Then the second is controlling the quantity of imports of shallots. The third is trying to make local shallots prices compete with imported shallots and the last is giving incentives to farmers in an effort to increase the amount of shallot production. 


\section{ACKNOWLEDGEMENTS}

The author would like to thank all those who have supported this research. To the Central Bureau of Statistics, the Department of Agriculture and the Trade Office of Probolinggi Regency who have been willing to present data to support this research. We would also like to thank the Editorial Board of the Agrise Journal for taking the time to review and provide constructive suggestions before publication.

\section{REFERENCES}

Anindita R. 2008. An economic approach to price analysis. Jakarta (ID): Kencana Prenada Media Group.

[BPS] Badan Pusat Statistik. 2019. Production and consumption of shallots in Indonesia. Jakarta (ID): Badan Pusat Statistik.

Bollerslev T. 1986. Generalized autoregressive conditional heteroskedasticity. J Econometrics. 31(3):307-327. https://doi.org/10.1016/03044076(86)90063-1.

Gujarati DN. 2006. Econometrics basics. Jakarta (ID): Erlangga.

Hugida L. 2011. Analysis of the factors that influence the volatility of stock prices (study of companies listed in the LQ45 index for the period 2006-2009). Jurnal Skripsi. http://eprints.undip.ac.id/29812 diakses pada 11 Februari 2021.

Ministry Of Trade. 2019. Overview of the shallot market. Jakarta (ID): Kementerian Perdagangan.

Moledina, A. A., T. L. Roe, and M. Shane. 2003. Measuring commodity price volatility and the welfare consequences of eliminating volatility.
Working paper, USDA/ERS and the Economic Development Center, University of Minnesota. Nizar MA. 2012. The impact of fluctuations in world oil prices on the Indonesian economy. Bul Ilm Penelit Pembang Perdag. 6(2):189-220. https://doi.org/10.30908/bilp.v6i2.131.

Paranata, Ade, Ahmad TU. 2015. The effect of shallot prices on shallot production in Central Java. Journal Of Economics and Policy. 8(1):36-44. http://dx.doi.org/10.15294/jejak.v8i1.3852

Pardian P, Noor TI, Kusumah A. 2016. Analysis of the supply and demand for shallots in West Java Province. Agricore. 1(2):149-157.

Pasaribu TW, Daulay M. 2013. Analysis of the import demand for shallots in Indonesia. J Ekon Keuangan. 1(4):14-26.

Putri RH, Watemin. 2014. Trend analysis and estimated price of shallots in Banyumas Regency for the period of January 2008-2017. J Dinamika Ekon Bisnis. 11(1):65-69.

Sarjani AS, Palupi ER, Suhartono MR, Purwanto YA. 2018. Effect of storage room temperature and treatment of shallot seed tubers (Allium cepa L. group Aggregatum). J Hort Indones. 9(2):111-121.

Sahara, Utari MH, Azijah Z. 2019. The volatility of shallot prices in Indonesia. Bul Ilm Penelit Pembang Perdag 13(2):309-336. https://doi.org/10.30908/bilp.v13i2.419.

Sumaryanto. 2009. Analysis of retail price volatility of several major food commodities using the ARCH / GARCH model. J Agro Ekon. 27(2):135-163. http://dx.doi.org/10.21082/jae.v27n2.2009.135 -163 . 
This page is intentionally left blank 